УДК 94(430):358.1

ТКАЧУК П. П.

ХАРУК А. I.

\title{
СТВОРЕННЯ В НІМЕЧЧИНІ ВАЖКИХ ПОЛЬОВИХ ГАУБИЦЬ НАПЕРЕДОДНІ ТА ПІД ЧАС ДРУГОЇ СВІТОВОЇ ВІЙНИ
}

У статті розглянуто історію створення та основні характеристики німецьких важких польових гаубиць. Основна увага зосереджена на базовій моделі sFH 18. Поряд із тим, проаналізовано спроби створення полегшених варіантів важкої польової гаубиці (sFH 36, sFH 40, sFH 42). Здійснено порівняльний аналіз гаубиці sFH 18 з iі основними зарубіжними відповідниками - радянською гаубицею М-10 і американською М1.

Ключові слова: Німеччина, Друга світова війна, артилерія, польова гаубиця.

Постановка проблеми та ї̈ актуальність. Формуючи структуру артилерійських частин вермахту у 1930-х рр., німецькі військові фахівці послідовно проводили лінію на «гаубизацію» дивізійної артилерії. Саме гаубиці були визнані оптимальним типом артилерійських систем для наступальних дій під час бліцкригу. Основними взірцями стали дві артсистеми: 105-мм легка польова гаубиця leFH 18 і 150-мм важка гаубиця sFH 18. У типовому варіанті артполк піхотної дивізії вермахту мав три дивізіони легких гаубиць і один - важких. Важкі гаубиці застосовувались і у дивізіях інших типів. Вони стали одним з найбільш розповсюджених артилерійських систем вермахту та військ СС у Другій світовій війні. Однак досі у вітчизняній історіографії практично відсутні роботи, присвячені історії створення та удосконалення гаубиці sFH 18.

Аналіз попередніх досліджень. Досвід створення та використання німецьких важких польових гаубиць розглядався, зокрема, у працях Й. Енгельмана [1; 2] Т. Гандера і П. Чемберлена [3].

Ткачук Павло Петрович, доктор історичних наук, професор, заслужений діяч освіти України, Національна академія сухопутних військ імені гетьмана Петра Сагайдачного, м. Львів.

Харук Андрій Іванович, доктор історичних наук, професор, завідувач кафедри гуманітарних наук, Національна академія сухопутних військ імені гетьмана Петра Сагайдачного, м. Львів.

(C) Ткачук П.П., Харук А.І., 2018 
Певний інтерес становить довідник 3 німецької артилерії, виданий в СРСР ще у 1943 р. [4]. Автори даної статті теж досліджували окремі аспекти цього питання у монографії «Польова артилерія Другої світової війни» [5].

Мета та завдання дослідження. Дана стаття має на меті дослідити історію створення та розвитку німецьких важких польових гаубиць періоду Другої світової війни, насамперед, sFH 18 та похідних від неї.

Виклад основного матеріалу. Німецькі військові одними 3 перших у світі гідно оцінили якості важких польових гаубиць. У 1902-1903 рр. в кайзерівській армії сформували перші п’ять дивізіонів 150-мм гаубиць (власне, їх калібр складав 149,1 мм, але в усіх документах вони i їх наступники проходили як «15-см»). На озброєння цих дивізіонів надійшли гаубиці sFH 02. Саме вони й складали основу важкої польової артилерії, яка напередодні Першої світової війни складалась з 25 полків (840 гаубиць $\mathrm{sFH} \mathrm{02)}$ [2, p. 3].

У 1913 р. для заміни sFH 02 концерн «Крупп» створив нову 150-мм гаубицю sFH 13. Від попередниці вона відрізнялась збільшеною з 12 до 14 калібрів довжиною ствола, наявністю щита та низкою інших удосконалень. Маса sFH 13 у похідному положенні не перевищувала 3 т, що дозволяло транспортувати іiі шестикінним запрягом [3, p. 198]. В жовтні 1914 p. sFH 13 дебютували у бою. Під час виробництва гаубицю модернізували: пружинне гальмо відкоту замінили гідравлічним, а згодом збільшили довжину ствола до 17 калібрів (для підвищення дальності стрільби) і зменшили кількість нарізів (для зниження зносу ствола). Удосконалена гаубиця позначалась $\mathrm{sFH} 13 \mathrm{lg}$ (langen - «довга»). Загалом виготовили 3409 гаубиць sFH 13 [6, s. 4]. Крім кайзерівської армії, вони постачались Туреччині, а після Першої світової війни потрапили на озброєння армій Бельгії, Нідерландів, Литви та Латвії [7, с. 44].

Версальський мирний договір суттєво обмежив кількість і номенклатуру артсистем (насамперед, великих калібрів), які залишались на озброєнні армії Німеччини. До того ж, заборонялась розробка нових взірців. Питання про відновлення виробництва важких артсистем постало після завершення в лютому 1927 р. роботи в Німеччині Міжсоюзницької контрольної комісії. Пропозиція відновити випуск гаубиць $\mathrm{sFH} 13 \mathrm{lg}$ була відкинута військові потребували системи зі значно більшою дальністю 
стрільби та кутом горизонтального наведення. За наполяганням Відділу озброєнь сухопутних військ конструкторські бюро концернів «Крупп» і «Рейнметал» тісно співпрацювали при створенні нової важкої польової гаубиці, яка отримала позначення $15 \mathrm{~cm}$ schwere Feldhaubitze 18 (sFH 18), тобто «15-см важка польова гаубиця зразка 1918 р.» (рік прийняття на озброєння, як і випадку 3 легкою гаубицею leFH 18, був фальшивим - він мав створити враження, що гаубиця була створена ще до укладення Версальського договору). Фахівці «Круппа» займались проектуванням ствола. Усі роботи, включаючи проектування, виготовлення дослідних екземплярів та їх випробування, тривали близько трьох років [4, с. $31-32]$.

Важка польова гаубиця sFH 18 мала ствол калібром 149,1 мм i довжиною 4400 мм (29,5 калібрів), без дульного гальма. Ствол складався 3 труби, кожуха і казенника. Затвор - клиновий горизонтальний. Гальмо відкоту і накатник - гідравлічні. Гальмо відкоту знаходилось в колисці, накатник - над стволом. Підйомний механізм - гвинтовий, урівноважувальний - пружинний (складався 3 двох колонок) [4, с. $31-32]$.

Значно довший, ніж у sFH 13, ствол нової гаубиці забезпечував снарядові максимальну початкову швидкість 520 м/с. Дальність стрільби сягала 13300 м (для sFH 13 вона не перевищувала 8800 м).

Лафет із розсувними станинами коробчастого перерізу був уніфікований з лафетом 105-мм гармати К 18. Він забезпечував кут горизонтального наведення $60^{\circ}$ (замість $5^{\circ}$ для $\mathrm{sFH} \mathrm{13).}$ Діапазон кутів вертикального наведення становив від $0^{\circ}$ до $+45^{\circ}$. В екстрених випадках допускалось ведення вогню зі зведеними станинами, але максимальний кут піднесення при цьому не перевищував $+15^{\circ}$, а кут горизонтального наведення складав $6^{\circ}$ $[8$, s. 7-8].

Платою за поліпшення вогневих характеристик sFH 18 стало значне зростання іiі маси порівняно із попередницею. Для економії маси довелось навіть відмовитись від щита: передбачалось, що 150-мм гаубиці будуть вести вогонь прямою наводкою 3 відкритих вогневих позицій лише у виняткових випадках. Але це мало допомогло. Маса системи в похідному положенні перевищувала 6 тонн - удвічі більше, ніж у sFH 13. Тому кінною тягою sFH 18 могла транспортуватись тільки роздільно. Ствол за допомогою ручної лебідки знімався з лафета $\mathrm{i}$ поміщався на двовісний ствольний візок, сполучений з передком. 
Цей візок, а також лафет із передком транспортувались шестикінними запрягами. Приведення гаубиці з похідного положення у бойове i, навпаки, було досить трудомістким та потребувало зусиль усіх 12 чоловік обслуги. Добре тренована обслуга витрачала на це 5-7 хвилин.

Механічною тягою гаубиця транспортувалась одним напівгусеничним тягачем. Процес приведення у похідне положення значно спрощувався: слід було лише зняти сошники зі станин, звести станини, підняти їх на передок і відтягнути ствол у похідне положення. Все це займало 3-4 хвилини. Як і багато інших німецьких артсистем, sFH 18 комплектувалась різними колесами для кінної та механічної тяги: у першому випадку використовувались колеса діаметром 1300 мм із сталевими шинами, у другому діаметром 1230 мм із суцільними гумовими шинами [2, p. 21].

Боєкомплект гаубиці sFH 18 спочатку складався із трьох типів снарядів. Основним був осколково-фугасний снаряд $15 \mathrm{~cm} \mathrm{Gr.} 19$ масою 43,62 кг. Він споряджався ударним і механічним дистанційним підривачами. При використанні дистанційного підривача i підриві на оптимальній висоті близько 10 м уламки летіли вперед на 26 м і в боки на 60-65 м, назад уламки не летіли. Коли спрацьовував ударний підривач при влучанні в грунт уламки летіли на 20 м вперед, 50 м в боки і 6 м назад. Снаряд пробивав бетонну стіну завтовшки до 0,45 м, цегляну - до 3,05 м, піщаний грунт - до 5,5 м. Крім того, використовувались бетонобійний снаряд $15 \mathrm{~cm} \mathrm{Gr} .19$ Beton масою 37,88 кг і димовий $15 \mathrm{~cm} \mathrm{Gr.} 19 \mathrm{Nb}$ масою 38,97 кг.

У другій половині 1930 - на початку 1940-х років номенклатура боєприпасів розширилась за рахунок нових взірців. На озброєння прийняли покращений осколково-фугасний снаряд 15 cm Gr. 36 FES масою 38,5 кг. Два типи снарядів призначались для боротьби 3 танками. Кумулятивний снаряд $15 \mathrm{~cm} \mathrm{Gr} .36 \mathrm{FES}-\mathrm{HI} / \mathrm{A}$ масою 24,83 кг (перший кумулятивний снаряд, прийнятий на озброєння вермахту) міг пробити 150-200 мм броні при куті зустрічі $45^{\circ}$ від нормалі, що дозволяло уражати танки будь-яких типів, включно iз важкими. Бронебійний підкаліберний снаряд 15 cm PzGr. 39 TS важив 15 кг. На дистанції 1000 м він пробивав броню завтовшки 126 мм [9, p. 28].

Заряджання гаубиці - роздільно-гільзове. У гільзі завдовжки 260 мм 3 діаметром фланця 176 мм знаходився пакет і п’ять різноважних пучків пороху. Крім того, окремо перевозились 
пучки № 7 і № 8 особливого заряду. При стрільбі зарядом № 73 гільзи видаляли пакет і пучки, а замість них вкладали пучок № 7. Заряд № 8 отримували додаванням до пучка № 7 пучка № 8 . Вогонь на зарядах 31 по 6-й дозволявся без жодних обмежень. Застосування 7 і 8-го зарядів дозволялось тільки в особливих випадках і з дозволу вищого командування, а кількість пострілів на цих зарядах обмежувалась не більше ніж десятьма підряд (через прискорене зношування зарядної камори) [7, с. 46].

Серійне виробництво гаубиць sFH 18 почалось наприкінці 1933 р. і тривало аж до поразки Німеччини у Другій світовій війні. Спочатку його здійснював концерн «Рейнметал-Борзіг» на заводі у Дюссельдорфі. Частина стволів надходила 3 заводу «Крупп». Згодом складання sFH 18 налагодили на заводах «Шпреєверк» (Берлін-Шпандау), МАН (Аугсбург) i «Дьорріс-Фюлльнер» (Бад-Вармбрунн). Уже під час Другої світової війни виробництво таких гаубиць освоїв завод «Шкода» (м. Дубніце-над-Вагем, Словаччина) [1, p. 47].

Дані про точну кількість гаубиць sFH 18, випущених у 1933 1945 рр., в опублікованих джерелах відсутні. Вважається, що до початку Другої світової війни вермахт отримав близько двох тисяч таких артсистем, а темп випуску досягав 30 одиниць на місяць. Після початку війни обсяги виробництва зросли, однак досягти наміченого темпу випуску 300 одиниць на місяць не вдалось. У вересні-грудні 1939 р. виготовили 190 sFH 18, 1940 р. 580, 1941-го - 516, 1942- го - 636, 1943-го - 758. У 1944 р. було досягнуто рекордних показників випуску важких польових гаубиць - 2295 одиниць, а 1945 року виготовили 401 sFH 18. Таким чином, загальний обсяг виробництва $\mathrm{sFH} 18$ склав приблизно 7,5 тисяч одиниць [1, p. 47].

У 1942 р. почалось виробництво варіанта sFH 18M, що обладнувався дульним гальмом. Завдяки цьому нововведенню вдалось зменшити навантаження, що діяли на лафет гаубиці при пострілі. Одночасно частково розв'язали проблему стрільби на 7 і 8 -му зарядах, запровадивши в конструкцію зарядної камори змінні вкладиші - тепер після досягнення граничного зношення їх можна було легко замінити, тоді як раніше потрібно було заміняти цілий ствол.

Гаубиця sFH 18M стала першою німецькою артилерійською системою, в боєкомплект якої увійшов активно-реактивний снаряд. Цей снаряд - 15 cm R Gr - важив 45,25 кг, а дальність стрільби 
ним сягала 19000 м [4, с. 32]. Завдяки цьому гаубиця набула здатності уражати цілі на відстанях, раніше досяжних лише для 105-мм гармат К 18. Це зумовило прийнято рішення про припинення виробництва гармат К 18, хоча самі активно-реактивні снаряди були ще дуже недосконалими - наприклад, розсіювання снарядів на максимальній дальності стрільби сягало 1250 м [10, p. 75].

Серйозним недоліком гаубиці sFH 18 була іiі маса, що суттєво обмежувало мобільність дивізійної артилерії - в артполках піхотних дивізій вермахту використовувалась виключно кінна тяга. Тому ще у 1935 р. за вказівкою Відділу озброєнь сухопутних військ фірми «Крупп» i «Рейнметал» розпочали проектування полегшеної 150-мм гаубиці, яка мала транспортуватись одним шестикінним запрягом. Нова гаубиця $-15 \mathrm{~cm}$ schwere Feldhaubitze 36 (sFH 36), мала вкорочений на 890 мм ствол із дульним гальмом, а в конструкції лафета застосовували легкі сплави. Масу гаубиці вдалось знизити до прийнятної величини - 3500 кг, але максимальна дальність стрільби також дещо знизилась (до 12500 м). Прототип sFH 36 був готовий у 1938 р., а наступного року почалось дрібносерійне виробництво. Однак вже у 1941 р. його припинили через дефіцит легких сплавів, вкрай потрібних для авіаційної промисловості [9, р. 28].

У 1938 р. «Крупп» і «Рейнметал» почали розробку ще одного варіанту 150- мм гаубиці, призначеного на цей раз виключно для транспортування механічною тягою. Конструкторам вдалось, подовживши ствол на 3 калібри, збільшити дальність стрільби до 15675 м. Суттєво був збільшений і кут піднесення - до $+70^{\circ}$. Дослідний екземпляр гаубиці $15 \mathrm{~cm}$ schwere Feldhaubitze 40 (sFH 40) був готовий у тому ж 1938 р. Але рішення про його впровадження у виробництво було заблоковане Верховним командуванням вермахту, яке вимагало у першу чергу збільшення випуску артилерійських систем, що вже знаходились у виробництві. Зрештою, у 1940 р. роботи зі створення sFH 40 були припинені [3, p. 200].

Щоб використати підготовлений запас вузлів, у 1942 р. невелику кількість стволів SFH 40, виготовлених заводом «Крупп» в Ессені, наклали на лафети гаубиць sFH 18. Такий «гібрид» отримав позначення sFH 18/40, яке пізніше змінили на sFH 42. Гаубиця виявилась не надто вдалою: порівняно із sFH 40 зменшився кут піднесення, а отже - можливість ведення вогню на короткі відстані; максимальна дальність стрільби теж дещо знизилась. До того ж, вартість гаубиці зросла на 50\% 
порівняно 3 sFH 18 - до 60 тис. рейхсмарок замість 40 тис. Тому випуск sFH 42 обмежився лише 46 одиницями [1, p. 21]. Таким чином, усі зусилля фахівців фірм «Крупп» $\mathrm{i}$ «Рейнметал» 3 удосконалення 150-мм гаубиць виявились марними. Аж до кінця війни основними типами таких артсистем у вермахті та військах СС залишались sFH 18 i sFH 18M.

Основні характеристики німецьких важких польових гаубиць наведені в таблиці 1 (складена за [5, с. 38-39]).

Гаубиці sFH 18 ще до початку Другої світової війни почали надходити на експорт: у 1930-х роках 24 (за іншими даними, 32) такі артсистеми купив Китай. В роки Другої світової війни sFH 18 постачались країнам-союзницям Німеччини. Зокрема, в жовтні 1940 р. 48 таких гаубиць отримала Фінляндія.

Таблицяя 1

Тактико-технічні характеристики німецьких 150-мм гаубиць

\begin{tabular}{|l|c|c|c|c|c|}
\hline Характеристики & $\mathrm{sFH} 13 \mathrm{lg}$ & $\mathrm{sFH} 18$ & $\mathrm{sFH} \mathrm{36}$ & $\mathrm{sFH} \mathrm{40}$ & $\mathrm{sFH} \mathrm{42}$ \\
\hline $\begin{array}{l}\text { Довжина ствола, } \\
\text { мм/клб }\end{array}$ & $2550 / 17$ & $4440 / 29,5$ & $3555 / 23,7$ & $4875 / 32,5$ & $4875 / 32,5$ \\
\hline $\begin{array}{l}\text { Куг вертикального } \\
\text { наведення, град. }\end{array}$ & $0,+45$ & $0,+45$ & $-1,+43$ & $-1,+70$ & $0,+45$ \\
\hline $\begin{array}{l}\text { Куг горизонтально- } \\
\text { го наведення, град. }\end{array}$ & 5 & 60 & 56 & 60 & 56 \\
\hline $\begin{array}{l}\text { Швидкострільність, } \\
\text { постр./хв }\end{array}$ & 4 & 4 & 4 & 4 & 4 \\
\hline $\begin{array}{l}\text { Маса у бойовому } \\
\text { положенні, кг }\end{array}$ & 2250 & 5512 & 3280 & 5680 & 5660 \\
\hline $\begin{array}{l}\text { Маса в похідному } \\
\text { положенні, кг }\end{array}$ & 3000 & 6304 & 3500 & 6400 & 6480 \\
\hline $\begin{array}{l}\text { Максимальна } \\
\text { початкова швидкість } \\
\text { снаряда, м/с }\end{array}$ & 381 & 520 & 485 & 595 & 595 \\
\hline $\begin{array}{l}\text { Максимальна даль- } \\
\text { ність стрільби, м }\end{array}$ & 8675 & 13325 & 12500 & 15100 & 15675 \\
\hline
\end{tabular}

Наприкінці 1980-х років фінські sFH 18 пройшли модернізацію: вони отримали нові стволи калібру 152 мм. У 1941 р. 38 гаубиць sFH 18 поставили Італії [6, s. 36]. У повоєнні роки трофейні sFH 18 знаходились на озброєнні в Албанії, Югославії, Чехословаччині. Чехословацькі sFH 18 пройшли модернізацію: їх пристосували для стрільби 152-мм снарядами радянського взірця та обладнали дульними гальмами покращеної конструкції. Така гаубиця позначалась vZ. 18/47N [8, s. 31]. 
Гаубиці sFH 18 застосувались вермахтом і військами СC на всіх етапах війни та всіх театрах воєнних дій. Вони вважались достатньо надійною та потужною зброєю. Наявність у боєкомплекті кумулятивних та підкаліберних бронебійних снарядів дозволяла застосовувати sFH 18 як протитанковий засіб, однак використовували цю можливість вкрай рідко: великі розміри гаубиці та відсутність щитового прикриття робили гаубицю легкою мішенню на полі бою.

Після того, як вермахт зіткнувся з Червоною Армією дальність вогню sFH 18 виявилась недостатньою: радянська 152-мм гармата-гаубиця МЛ-20 стріляла на 17300 м, a sFH 18 - лише на 13325 м. Введення у боєкомплект гаубиці активно-реактивного снаряда допомогло мало, оскільки розсіювання нового снаряда було надто великим.

Як же виглядала sFH 18 на фоні артсистем армій противників? Клас важких гаубиць в дивізійній ланці станом на 1941 р. був наявний у трьох країнах: СРСР, Німеччині та США, де були створені й прийняті на озброєння сучасні зразки таких артсистем калібром 150-155 мм: М-10 (зразка 1938 р.; виготовлено понад 1,5 тисячі) в Радянському Союзі, sFH 18 в Німеччині (приблизно 7,5 тисячі) та М1 у США (понад 4 тисячі - без врахування післявоєнного випуску). Їхні основні характеристики наведені в таблиці 2 (складена за [5, с. 181-182]).

Таблиия 2

Порівняльна характеристика важких дивізійних гаубиць періоду Другої світової війни

\begin{tabular}{|l|c|c|c|}
\hline \multicolumn{1}{|c|}{ Країна } & Німеччина & США & СРСР \\
\hline Тип артсистеми & sFН 18 & М1 & зразка 1938 p. (M-10) \\
\hline Калібр, мм & 149,1 & 155 & 152,4 \\
\hline Довжина ствола, мм/клб & $4440 / 29,5$ & $3099 / 20$ & $3700 / 24,3$ \\
\hline $\begin{array}{l}\text { Кут вертикального } \\
\text { наведення, град. }\end{array}$ & $0,+45$ & $-5,+63$ & $-1,+65$ \\
\hline $\begin{array}{l}\text { Кут горизонтального } \\
\text { наведення, град. }\end{array}$ & 60 & 49 & 50 \\
\hline $\begin{array}{l}\text { Швидкострільність, } \\
\text { постр./хв }\end{array}$ & 4 & 2 & $3-4$ \\
\hline $\begin{array}{l}\text { Маса у бойовому } \\
\text { положенні, кг }\end{array}$ & 5512 & 5427 & 4100 \\
\hline $\begin{array}{l}\text { Маса в похідному } \\
\text { положенні, кг }\end{array}$ & 6304 & 5800 & 4550 \\
\hline $\begin{array}{l}\text { Маса осколково-фугас- } \\
\text { ного снаряда, кг }\end{array}$ & 43 & 43 & 40 \\
\hline $\begin{array}{l}\text { Максимальна початкова } \\
\text { швидкість снаряда, м/с }\end{array}$ & 520 & 564 & 525 \\
\hline $\begin{array}{l}\text { Максимальна дальність } \\
\text { стрільби, м }\end{array}$ & 13325 & 14955 & 12800 \\
\hline
\end{tabular}


Радянська гаубиця М-10 порівняно з аналогами мала найкращі масогабаритні характеристики. Це дозволяло транспортувати iі одним візком не тільки механічною, але й кінною тягою (хоча штатним засобом буксирування залишався тягач). Німецька гаубиця sFH 18, як вже зазначалось, могла транспортуватись кінною тягою лише двома візками, а мобільність їі на механічній тязі обмежувалась відсутністю підресорювання (у радянській М-10 i американській M1 колісний хід був підресорений). Для гаубиці M1 досить значна маса не була серйозною вадою, оскільки в армії США використовувалась виключно механічна тяга [11, p. 56].

Потужність снарядів усіх трьох гаубиць була приблизно однакова. За дальністю стрільби американська система суттєво переважала конкурентів, однак поступалась їм у швидкострільності. Причиною було картузне заряджання M1 (sFH 18 i M-10 мали роздільно-гільзове заряджання) [12, p. 77]. Однак аналізуючи ці всі параметри, ми не повинні забувати того факту, що вже з літа 1941 р. важкі гаубиці були виведені зі складу дивізійної артилерії Червоної Армії, тоді як у Німеччині вони залишались невід'ємним компонентом дивізійної артилерії до самого кінця війни. Схожою була ситуація і в США - 3 тією лише різницею, що в американській армії важкі гаубиці були тільки в піхотних дивізіях, а танкові їх не мали.

Загалом гаубиця sFH 18 була типовим зразком німецької артилерійської системи, спроектованої у міжвоєнний період: надійна, міцна конструкція із не надто видатними, але цілком задовільними тактико-технічними характеристиками.

1. Engelman J. Deutsche schwere Feldhaubitzen 1934-1945 / J. Engelman. - Friedberg: Podzun-Pallas-Verlag, 1992. - 48 p.

2. Engelman J. German Heavy Field Artillery 19341945 / J. Engelman. - Atglen: Schiffer Publication, 1995. - 48 p.

3. Gander T. Enzyklopädie deutscher Waffen 19391945 / T. Gander, P. Chamberlain. - Stuttgart: Motorbuch Verlag, 2004. $-372 \mathrm{p}$.

4. Вооружение германской артиллерии / Под ред. В.И. Хохлова. - Изд. 2-е, испр. и доп. - М.: Гос. изд-во оборон. пром-сти, 1943. - 176 с.

5. Польова артилерія Другої світової війни: Історичний нарис: Монографія / П.П. Ткачук, А.І. Харук, О.П. Красюк. Львів: НАCВ, 2016. - 194 с.

6. Skotnicki M. $15 \mathrm{~cm}$ s.F.H. 13/1(Sf). Nowe życie starej haubicy / M. Skotnicki // Technika Wojskowa Historia. 2010. - № 5. - S. 4- 11. 
7. Харук A. 150-мм тяжелая полевая гаубица sFH 18 / А. Харук // Наука и техника. - 2016. - № 2. - С. 44-50.

8. Skotnicki M. Ciężka haubica polowa s.F.H. 18 / M. Skotnicki. - Warszawa: ZP, 2011. - 40 s.

9. Skotnicki M. Ciężka haubica polowa s.F.H. 18 / M. Skotnicki // Nowa Technika Wojskowa. - 1998. - № 4. S. 26-31.

10. Широкорад А.Б. Бог войны Третьего рейха / А.Б. Широко-рад. - М.: АСТ, 2003. - 576 с.

11. Doyle D. High Speed Tractor: A visual history of U.S. Army's tracked artillery prime mover / D. Doyle, P. Stansell. - Delray Beech: Ampersand Publishing, 2006. - 112 p.

12. Hogg I.V. Allied Artillery of World War Two / I.V. Hogg. - London: Crowood Press, 2007. - 206 p.

Надійшла до редколегії 07.02.2018 р.

Рецензент: О.Й. Дем'янюк, доктор історичних наук, професор, проректор 3 науково-педагогічної роботи та моніторингу якості освіти Волинського інституту післядипломної педагогічної освіти, м. Луцьк.

\section{Tkachuk Pavlo, Kharuk Andriy \\ CREATION OF HEAVY FIELD HOWITZERS IN GERMANY ON THE EVE AND DURING THE SECOND WORLD WAR}

The article analyzes the history of creation and the main characteristics of the German heavy field howitzers. The main focus is on the base model sFH 18. It also analyzes the attempts of creating lightweight variants of heavy field howitzer (sFH 36, $\mathrm{sFH} 40$ and sFH 42). A comparative analysis of howitzer sFH 18 with its main foreign correspondents - the Soviet howitzer M-10 and the American M1- have been carried out in this work.

Keywords: Germany, Second World War, artillery, field howitzer. 